\title{
Cytogenetics of Colletotrichum lindemuthianum (Glomerella cingulata f. sp. phaseoli)*
}

\author{
M. Gabriela Roca M., Lisete C. Davide* \& Maria C. Mendes-Costa \\ Laboratorio de Citogenetica, Departamento de Biologia, Universidade Federal de Lavras, Cx. Postal 37, Lavras, MG, \\ CEP37200-000; e-mail: lcdavide@ufla.br
}

(Accepted for publication 05/02/2003)

Corresponding author: Lisete C. Davide

ROCA M., M.G., DAVIDE, L.C. \& MENDES-COSTA, M.C. Cytogenetics of Colletotrichum lindemuthianum (Glomerella cingulata f. sp. phaseoli): Fitopatologia Brasileira 28:367-373. 2003.

\begin{abstract}
Cytogenetic and morphological studies were conducted with Colletotrichum lindemuthianum (Glomerella cingulata f. sp.phaseoli), the pathogen responsible for anthracnose of common bean (Phaseolus vulgaris). In this species, there is some evidence of genomic variation but it is unknown whether the process occurs in a manner similar to other fungal genetic models. Six isolates from bean plants were used and sexual reproduction was observed in vitro. Meiosis and ascospore formation were investigated by cytogenetical approaches and light

microscopy. To study the nucleus and chromosome numbers, a mixture of carmine and orcein propionic dyes was used. Nucleus divisions as well as ascospore maturation were asynchronous. Meiosis was observed in three isolates. In the asexual form, chromosomal polymorphism in conidia was also observed microscopically and the mitosis process was described.

Additional keywords: conidia cytogenetics, chromosome polymorphism.

\section{RESUMO}

Citogenética de Colletotrichum lindemuthianum (Glomerella cingulata f. sp. phaseoli)

Um estudo citogenético e morfológico foi conduzido em Colletotrichum lindemuthianum (Glomerella cingulata f. sp. phaseoli), o patógeno responsável pela antracnose do feijoeiro (Phaseolus vulgaris). Nesta espécie há algumas evidências de variações genômicas, porém não se sabe se os processos envolvidos são análogos aos que ocorrem com fungos considerados modelos genéticos. Seis isolados de C. lindemuthianum do feijoeiro foram

utilizados e a reprodução sexual foi observada in vitro. A meiose e a formação de ascósporos foi estudada utilizando-se técnicas de citogenética e microscopia ótica pela primeira vez. O estudo do núcleo e o número de cromossomos foram estudados utilizando-se uma mistura dos corantes carmin e orceína propiônica. A divisão nuclear e a maturação dos ascósporos foram assincrônicas. A meiose foi observada em três isolados desta espécie. Na fase assexual, polimorfismo cromossômico nos conídios foi observado microscopicamente e o processo de mitose foi descrito.
\end{abstract}

\section{INTRODUCTION}

Colletotrichum lindemuthianum (Sacc. \& Magn.) Scribner is the fungus responsible for anthracnose, a serious disease of common bean (Phaseolus vulgaris L.) (Rava \& Sartorato, 1994; Perfect et al., 1999). The sexual form (teleomorph), Glomerella cingulata (Stonem.) Spauld. \& Schrenk f. sp. phaseoli, has never been found in nature. The genetics of the genus Glomerella were first studied by Edgerton (1912, 1914). Cytogenetic, morphogenetic and morphological studies have also been conducted with G. cingulata (Hüttig, 1935; Lucas, 1946; Wheeler et al., 1948; McGahen \& Wheeler, 1951; Uecker, 1994), but isolates from common bean were not included until recently (Roca et al., 2000). The sexual form of C. lindemuthianum was not reported until 1970 when the formation of fertile perithecia through crosses in culture medium was observed (Kimati \& Galli, 1970). Although genetic studies * Part of MS Thesis of the first author. Universidade Federal de Lavras.
(1998) have been carried out with G. cingulata strains isolated from bean plants (Batista \& Chaves, 1982; Bryson, 1990; MendesCosta, 1996, O'Sullivan et al., 1998), the only work with conventional cytogenetics in this genera was done in 1946 with strains isolated from Ipomea sp. (Lucas, 1946).

In C. lindemuthianum, chromosome polymorphism was found by pulsed-field gel electrophoresis (PFGE) (O'Sullivan et al., 1998), as in strains of Colletotrichum gloeosporioides (Penz.) Penz and Sacc. isolated from Stylosanthes spp. (Masel et al., 1990), and from Citrus spp. (Liyanage et al. 1992). O'Sullivan et al. (1998) reported that the study of genome structure with molecular cytogenetic analysis, which is normally conducted during meiosis, was not possible in $C$. lindemuthianum because of the absence of the sexual form. In C. lindemuthianum, there is still uncertainty about the number of chromosomes longer than $7 \mathrm{Mb}$ (O'Sullivan et al., 1998). In some filamentous fungi karyotyping by conventional light microscopy is not consistent with the electrophoretic karyotypes generated by PFGE. InNectria haematococca Berk and $\mathrm{Br}$. visualization of asci through conventional light 
microscopy led to an underestimation of the chromosome number and PFGE was effective for analysing chromosomes smaller than ca. $6 \mathrm{Mb}$ (Taga et al., 1998). Since no cytogenetic studies of the sexual stage of $C$. lindemuthianum ( $G$. cingulata f. sp. phaseoli) have been made so far, and given the excellent material at our disposal to compare with the asexual form, the aim of this study was to describe and to characterise both meiosis and ascospore formation in G. cingulata f. sp. phaseoli and to compare this process with the mitosis and the conidial chromosome number in the asexual form C. lindemuthianum, using light microscopy. The understanding of the cytogenetics of this fungi during sexual and asexual reproduction could help to explain the great variation reported in this specie in the asexual form.

\section{MATERIALSANDMETHODS}

\section{Colletotrichum strains and media}

The six Brazilian strains used in this study were originally isolated from bean plants and are now deposited in the culture collection of the Department of Biology, Federal University of Lavras, Minas Gerais, Brazil. Isolate numbers and their geographical origins are as follow: 531-Goiânia, GO; 1002-Lavras, MG; 1003-Viçosa, MG; 1007-Lavras, MG; 1010Lambari, MG and 1013-Patos, MG These strains were cultivated on PDA and M3 media (Junqueira et al., 1984).

\section{Cytogenetics of ascospores and asci}

Cytological preparations were made according to Robinow (1975), with modifications depending upon the strain. In order to stain asci, perithecia were fixed in $3: 1$ ethanol:propionic acid for $24 \mathrm{~h}$, crushed, suspended in this solution, and dropped onto slides. After air drying and heating in an oven at $40^{\circ} \mathrm{C}$, slides were stained for $24 \mathrm{~h}$ with a carmine and orcein dye mixture in $2 \%$ propionic acid one week later. Slides were then quickly washed in chloroform, followed by the fixative solution and dried at $40{ }^{\circ} \mathrm{C}$ for microscopic observation. Ascospores were measured with a micrometer eyepiece and a 40X magnification objective.

\section{Cytogenetics of conidia}

Fresh, ungerminated conidia were used for size measurements. Culture age was up to seven days and the conidia were measured with a micrometer eyepiece and a $40 \mathrm{X}$ objective for both free conidia and conidia from acervuli. Staining was used to identify conidial nuclei after seven days and to count chromosomes after 15 days. Except for the carmineorcein mixture, staining for cytogenetic study was made according to Robinow (1975), with some modifications, depending on the strain and nuclear phase (Table 1).

\section{Data and image analyses}

Photomicrography was carried out with a camera coupled to a Leica microscope. Black and white films, ISO 25 and 100, were used and pseudostaining with grey colours with Adobe Photoshop $^{\mathrm{TM}}$ v 2.5 and Jandel SigmaScan ${ }^{\circledR}$ Pro v 2.0 software permitted better identification of small chromosomes as well as the measurement and definition of pairing chromosomes.

\section{Sample size and statistics}

Evaluation of ascospore size (length and width) and chromosome numbers were performed in a fully randomized design with 30 and 35 replications, respectively. Chromosome counts were made for isolates 531 and 1013. The genotypic and phenotypic variances of ascospore size were estimated from the expected mean square by inserting the mathematical model into the operational formulas for mean squares from the one-way analysis of variance (ANOVA) (Hicks, 1993).

Evaluation on cell division in asci and formation of ascospores were performed with a minimum of 100 perithecia and scored as the number of observation most frequently found.

For evaluation of conidial size, a sample consisting of 100 fresh conidia was randomly chosen from five replicates. To count the number of nuclei per conidia, 500 ungerminated conidia were randomly chosen from five replicates after 15 days of culture. For strains 531 and 1002, counts of chromosome were undertaken from 60 ungerminated conidia, from different replicates of different plates. At least two different treatments were employed to count chromosome numbers (Table 1). The chromosome counts for strain 1013 were made with approximately ten ungerminated conidia from each of five replicates of each of five different plates (total number of 250 cells). In the latter analysis, the culture age was up to 25 days and only one staining treatment was used (Table 1). The same sample size was used to describe the mitosis process.

A one-way analysis of variance was carried out to account for the variation among and within strains, in relation to length and width of conidia. The effect of strain was considered to be a random one; therefore ANOVA was used to estimate genetic variance among strains by the method of moments (Hicks, 1993). This allowed for the estimation of inheritability in the broad sense, at the level of strain means for these traits. For chromosome numbers with strain 1013, a nested design was used; taking into account potential differences in plates, replicate slides for individual plates, and different conidia within any one slide. The effects of all these factors were considered to be random for the estimation of the corresponding components of variance.

\section{RESULTS}

The exuberant proliferation of perithecia was shown in culture medium (Figure 1). Each dark point is a cluster of perithecia which, when crushed, liberates many asci and ascospores. Since the details of the nuclear divisions in all perithecia were observed to be strikingly similar, the following descriptions, unless otherwise stated, apply equally well to asci of the three isolates studied.

\section{Ascus formation}

Ascus formation began with a strongly stained, centralcoiled cell that, in most cases, had a large nucleus, meaning 
Cytogenetics of Colletotrichum lindemuthianum

TABLE 1 - Treatment applied to conidia of Colletotrichum lindemuthianum for staining chromosomes and nuclei

\begin{tabular}{llllll}
\hline \hline $\mathbf{N}^{\mathbf{0}}$ & Strain & Fixation (hours) & HCl $^{*}$ & \multicolumn{1}{c}{ Stain (hours) } & \multicolumn{1}{c}{ Nuclei } \\
\hline 1 & 531 & Acet. Car (4-24) & $\mathrm{x}$ & Feulgen (12) & interphase, fragments \\
2 & 531 & Acet. Car (4-24) & $\mathrm{x}^{*}$ & Feulgen(12) + Acet. C. (12) & interph., frags., mitotic \\
3 & 531 & Prop. Car (24) & - & Prop. C-O (24) & mitotic \\
\hline 4 & 1002 & Acet. Car (24) & $\mathrm{x}$ & Feulgen (6) + C acet. (6) & interphase, mitotic \\
5 & 1002 & Prop. Car & $\mathrm{x}$ & Prop. C-O (12) & interphase \\
\hline 6 & 1003 & Acet. Car (24) & $\mathrm{x}$ & Feulgen (10-20) & mitotic \\
7 & 1003 & Prop. Car (24) & - & Prop. C. (24) & interphase \\
\hline 8 & 1007 & AFA (1) & $\mathrm{x}$ & Giemsa (0.5) & mitotic \\
\hline 9 & 1007 & Prop. Car (4-24) & - & Prop. C-O (24) & interphase \\
\hline 10 & 1010 & Acet. Car (4-24) & $\mathrm{x}$ & Feulgen (8) & interphase \\
\hline 11 & 1013 & Acet. Car (4-24) & $\mathrm{x}$ & Feulgen (10-12) & mitotic \\
\hline
\end{tabular}

$*$ Hydrolysis $=\mathrm{HCl} 60{ }^{\circ} \mathrm{C}, 1 \mathrm{~N}$ for $10 \mathrm{~min} ; *$ conidia with anastomosis

Acet. $\mathrm{Car}=$ acetic Carnoy: absolute ethanol: acetic acid (3:1, by vol.); Prop. Car = propionic Carnoy: absolute ethanol : propionic acid (3:1, by vol.); Acet. C. $=$ acetic carmine $2 \%$; Prop. C. = propionic carmine $2 \%$; Prop. C-O = propionic carmine-orcein $2 \%$; Feulgen = Schiff, modified by; Colleman (1938, cited by Robinow, 1975); Giemsa = Giemsa stain $2 \%$ in phosphate buffer $\mathrm{pH} 6.8$; AFA = 70\% ethanol, $90 \mathrm{ml}$; acetic acid, $3 \mathrm{ml} ; 45 \%$ formaldehyde, $5 \mathrm{ml}$.

that karyogamy had already occurred. The diameter of this fusion nucleus was of approximately $3.20 \mu \mathrm{m}$, contrasted to $1.76 \mu \mathrm{m}$ for the nuclei in the surrounding cells. Two nuclei, assumed to be haploid, were less often observed, meaning that fusion occurred quickly. The ascus then rapidly elongated and fusion nuclei attained their greatest length, $5.17 \mu \mathrm{m}$. In some of the early fusion nuclei, each nucleolus was observed attached to a large chromosome, the nucleolus-organizing chromosome.

\section{Chromosome number and meiotic divisions}

It was not generally possible to distinguish with certainty all of the individual chromosomes during pachytene, particularly the accurate pairing of bivalents in all the cells examined. Unpaired chromosomes were occasionally observed.

In late diplotene, knots and knobs suggestive of chiasmata, appeared at various points on the chromosomes. At late prophase I, four morphologically distinct chromosomes, assumed to be bivalents were seen, with the nucleolus (Figure $2 \mathrm{a}-\mathrm{b}$ ). The longest of these (approximately $1.10 \mu \mathrm{m}$ long) was bent near the centre in a manner characteristic of the nucleolusorganizing chromosome. At metaphase I, the nucleolus was still present as a reminiscent body, dissipating at the end of the metaphase.

The two shortest chromosomes were approximately 0.5 $\mu \mathrm{m}$ long. No nucleoli were visible after metaphase I and it seemed probable that chromosomes pass from telophase of division I to prophase of division II without nuclei being completely reformed. Only two reformed nuclei were seen in the rather large number of asci observed (more than a 100). Division II occurred quickly and closely followed division I so that division II figures occurred much less frequently than in the stage of nuclear fusion. The nucleolus did not reappear in prophase II. At the end of the meiosis, late-segregated chromosomes were observed (data not shown).

\section{Mitosis and ascospore formation}

After meiosis, mitosis appears to take place at once without reorganization of the four nuclei. At metaphase, four morphologically distinct chromosomes were again observed in each nucleus. Metaphase and anaphase nuclei were observed in a single ascus, which meant that mitosis and ascospore maturation were asynchronous (Figure 2c-d). Occasionally, some chromatic material, possibly lagging chromosomes, as well as variation in chromosome number were observed. Nuclear migration was seen to form several different patterns dependent on the isolate. Most frequently, nuclear migration occurred in the transverse axis of the ascus. After telophase, the eight nuclei reorganized after an oblique migration. As a result, eight ordered nuclei were seen to form and sometimes it was possible to determine sister nuclei. A disordered distribution of nuclei was observed (Figure 3). At maturity, the ascus contained eight nonseptate, uninucleate, slightly curved ascospores. Four- or six-spored asci were found

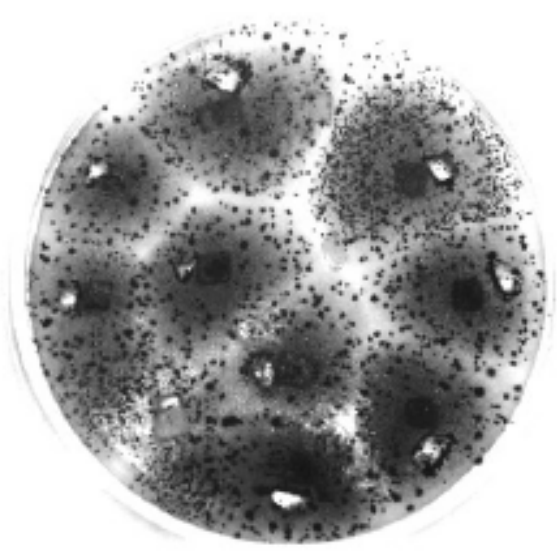

FIG. 1 - Proliferation of perithecia in culture media of Colletotrichum lindemuthianum (Glomerella cingulata f. sp. phaseoli). M3 media with 15 day-old culture. 


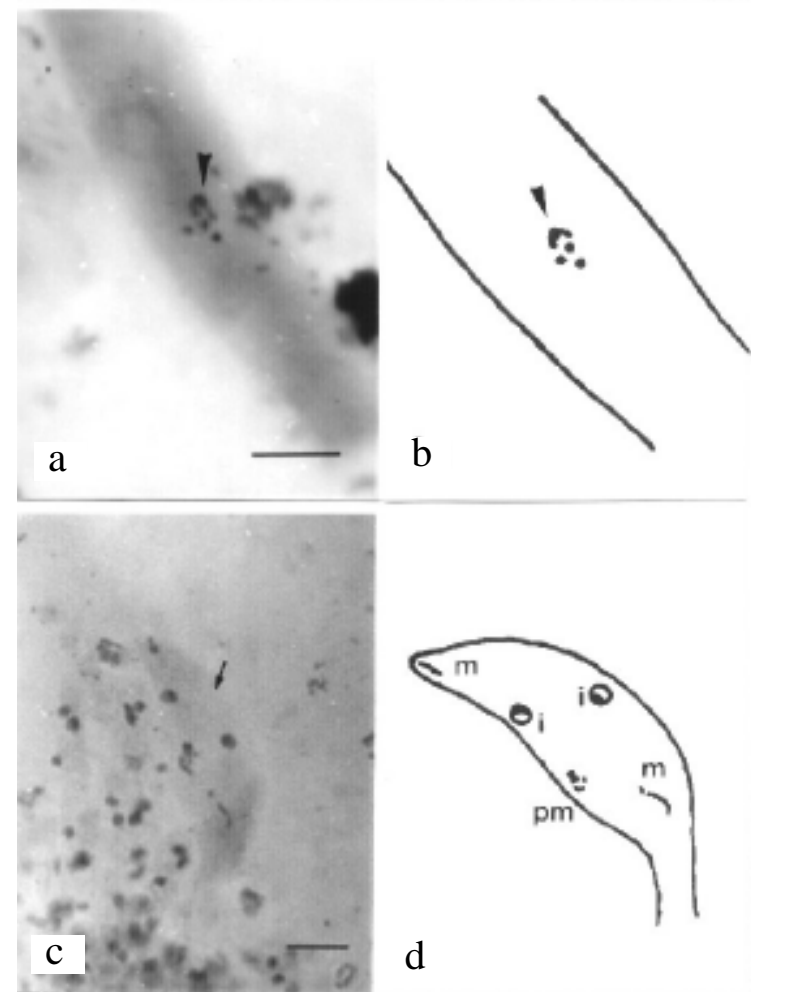

FIG. 2 - (a) Four chromosomes and nucleolus (arrowhead) at the ascus of Colletotrichum lindemuthianum (Glomerella cingulata f.sp. phaseoli). (b) Line drawing. (c) Asynchronous division in strain 531 ascus (arrow). (d) Line drawing nucleus at interphase (i), metaphase $(\mathrm{m})$, and pro-metaphase $(\mathrm{pm}) . \quad \mathrm{Bar}=5 \mu \mathrm{m}$. M3 media and 10 daysold culture

$(<20 \%)$. The nucleolus reappeared at the end of mitosis.

Statistically significant differences were observed for both length and width of ascospores $(\alpha=1 \%)$ as well as differences in division time of the ascus formation process. Phenotypic variation was due to genotypic differences between the isolates (Table 2).

\section{Mitosis and conidia cytogenetics}

Binucleate ungerminated conidia were found at a frequency that varied from $0 \%$ (strain 1010) to $2 \%$ (strains 531 , 1002 , and 1013). Length and width of conidia (Table 2) were significantly different in conidial size $(\alpha=1 \%)$, which meant that some genetic variance existed among strains. Strain 531 showed micronuclei in conidia at the interface (Figure 4). At prophase, a larger heteropycnotic area was identified as the nucleolus. Metaphase nuclei were often found at a polar position, and this permitted the counting of chromosomes. When more than four chromosomes were seen, there were usually two large, one medium, and a range of very small chromosomes. Differences between microscopic-slide preparations were found. For example, one slide had a mean of four chromosomes/nucleus and another, a mean of seven chromosomes/nucleus (Figure 4). Chromosome length at metaphase ranged from $0.26 \mu \mathrm{m}$ to $0.57 \mu \mathrm{m}$, the size at which they were most condensed. The nucleolus was still present at

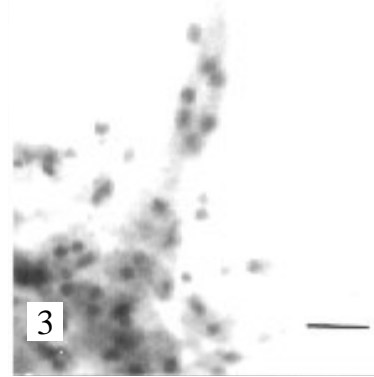

FIG. 3 - Disordered nuclei in ascus of strain 531 of Colletotrichum lindemuthianum. Bar $=5 \mu \mathrm{m}$. M3 media and 15 day-old culture.

TABLE 2 - Estimated parameters from measurement of ascospores of Colletotrichum lindemuthianum (strains 531, 1010, and 1013) and conidia (strains 531, 1002, 1003, 1007, 1010, and 1013) with light microscopy

\begin{tabular}{lccccl}
\hline \hline & $\sigma_{\mathbf{g}}^{2}$ & $\sigma_{\mathbf{p}} \mathbf{2}$ & $\mathbf{h}^{\mathbf{2}}$ & $\begin{array}{r}\text { Mean } \\
(\mathbf{m} \sigma)\end{array}$ & $\mathbf{C V}$ \\
\hline Ascospore length & 2.25 & 2.35 & $95.75 \%$ & 19.733 & $9.02 \%$ \\
Ascospore width & 1.38 & 1.41 & $97.87 \%$ & 5.816 & $17.12 \%$ \\
\hline Conidia length & 0.7845 & 0.8034 & $97.65 \%$ & 12.964 & $10.60 \%$ \\
Conidia width & 0.4264 & 0.4317 & $98.77 \%$ & 5.253 & $13.85 \%$ \\
\hline
\end{tabular}

$\sigma_{\mathrm{g}}^{2}=$ genotypic variance; $\sigma_{\mathrm{p}}^{2}=$ phenotypic variance $\left(\sigma_{\mathrm{p}}^{2}=\sigma_{\mathrm{g}}{ }^{2}+\left(\sigma^{2} / 100\right)\right.$ $\mathrm{h}^{\mathrm{g}}=$ heritability $\left(\mathrm{h}^{2}=\sigma_{\mathrm{g}}{ }^{2} / \mathrm{\sigma}_{\mathrm{p}}^{\mathrm{p}}\right) ; \mathrm{CV}=$ coefficient of variation

the beginning of the metaphase in strain 1002 (Figures 5a-d). The end of the metaphase was considered to take place when the nucleolus was completely desegregated (Figure 5e-f). For strain 1013, there was a significant difference $(\alpha=1 \%)$ for the chromosome number among plates and among microscope slide preparations within plates $(\alpha=5 \%)$. This strain had a mean of 5.52 chromosomes and a mode of four chromosomes/nucleus (Table 3). The results are given for only one slide/plate count with a mode of eight chromosomes (Table 3). In strains 531 and 1002 , the mean and mode of chromosome numbers were four (Table 3).

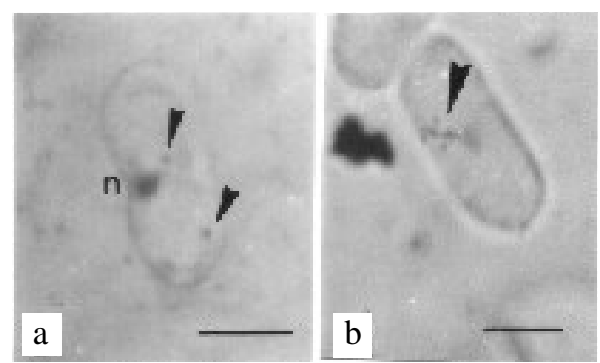

FIG. 4 - Conidia of Colletotrichum lindemuthianum. (a) Conidium with nucleus and micronuclei (arrowhead), treatment 2. (b) Conidium with seven chromosomes (arrowhead), treatment 2. Bar $=5 \mu \mathrm{m}$. M3 media and 20 day-old culture 


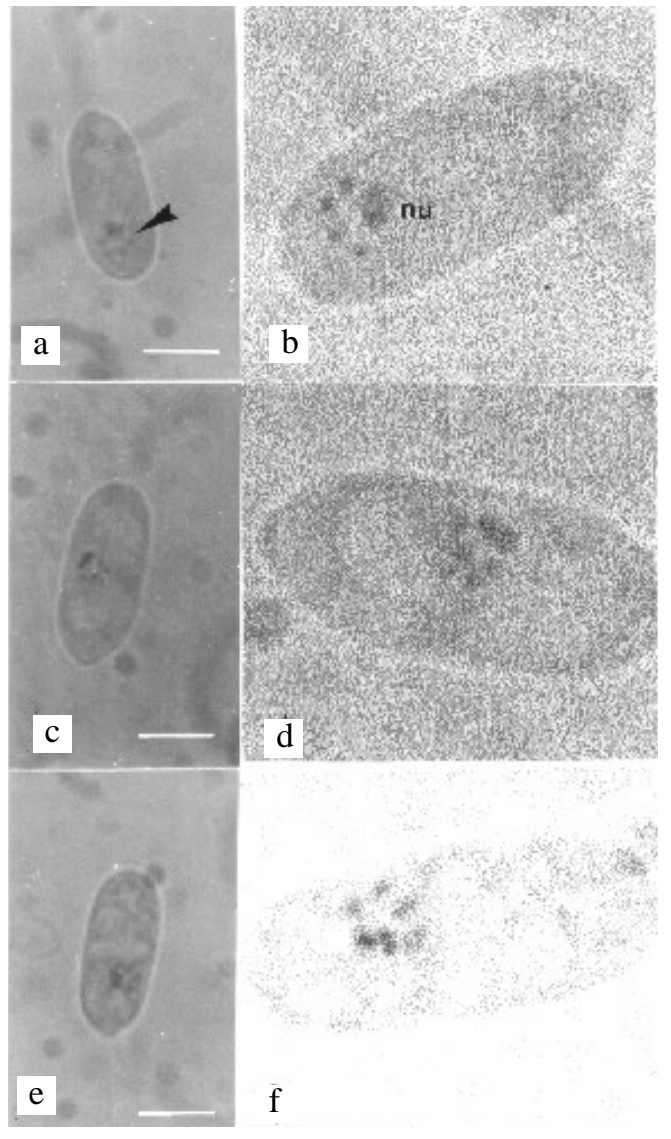

FIG. 5 - Variation in chromosome number in conidia of Colletotrichum lindemuthianum after 20 days of culture. M3 media. Strain 1002, treatment 5. (a) Conidia with four chromosomes and nucleolus. Arrowhead points to the nuclear area. (b) Pseudostaining picture of FIG. 5a, (nu) nucleolus. (c) Conidia with five chromosomes. (d) Pseudostaining picture of FIG. 5c. (e) Conidia with six chromosomes. (f) Pseudostaining picture of FIG. 5e. Bar $=5 \mu \mathrm{m}$

\section{DISCUSSION}

Our observations yielded information on chromosome number and description of the mitosis and meiosis process in this species. No attempt was made to obtain a defined karyotype for the species.

\section{Sexual form}

As demonstrated by Mendes-Costa (1996), perithecia of $G$. cingulata $\mathrm{f}$. sp. phaseoli formed spontaneously in culture medium and not only by mating (Kimati \& Galli, 1970; Batista \& Chaves, 1982; Bryson, 1990). The finding that most asci contained eight ascospores was evidence for fertility. The few abnormalities found during ascus and ascospore formation was further evidence for the few failures that could occur during this process. This meant that genes for sexual reproduction were still operating in some Glomerella isolates. The average size of the ascospores was close to the values found in other works for this genus (Wheeler \& Driver, 1953; Kimati \& Galli, 1970).
TABLE 3 - Frequency of the distribution of chromosome number in conidia of Colletotrichum lindemuthianum

\begin{tabular}{ccccc}
\hline \hline & \multicolumn{4}{c}{ strain } \\
\cline { 2 - 5 } Chromosome number & $\mathbf{5 3 1}$ & $\mathbf{1 0 0 2}$ & $\mathbf{1 0 1 3}$ & $\begin{array}{c}\mathbf{1 0 1 3} \\
\text { one plate }\end{array}$ \\
\hline 2 & 0 & 0 & 3 & 0 \\
3 & 3 & 3 & 11 & 0 \\
4 & 18 & 22 & 52 & 1 \\
5 & 14 & 14 & 16 & 0 \\
6 & 13 & 11 & 39 & 11 \\
7 & 10 & 2 & 30 & 13 \\
8 & 2 & 0 & 39 & 17 \\
9 & 0 & 0 & 10 & 5 \\
10 & 0 & 0 & 2 & 1 \\
16 & 0 & 0 & 2 & 1 \\
\hline Total number of conidia & 60 & 52 & 204 & 49 \\
mean & 4.22 & 4.75 & 5.52 & 7 \\
mode & 4 & 4 & 4 & 8 \\
\hline All & & & & 4 \\
\hline
\end{tabular}

All samples underwent treatments 2-5 and 12 .

The haploid chromosome number of four observed in the present study agrees with that reported by Lucas (1946) for G. cingulata isolated from Ipomoea sp. and on the conidia in this work. The unpaired chromosomes during pachytene could have originated as aneuploids in spore cells (Hrushovets, 1956; Knox-Davies \& Dickson, 1960). Variation in chromosome number generally lead to decreased fertility; this was probably responsible for the few asci observed with either four or six ascospores. One to eight ascospores with allantoid shape per ascus were found in the isolate $G$. cingulata from bean (Kimati \& Galli, 1970). In G. cingulata late-segregating chromosomes were found but not any chromosome number variation (Wheeler et al., 1948). In 1953, asci with four ascospores were observed by Wheeler \& Driver (1953), and they found a relation with chromosome and nucleus disintegration. In crosses among isolates of $G$. cingulata from different hosts, Cisar et al. (1994) found differences in the ascospores production varying from four to eight ascospores per ascus.

\section{Asexual form}

The fresh conidia of the strains used were considered dormant because it was very rare to find conidia with growing germ tubes prior to 15 days of culture. Most Colletotrichum species contain germination inhibitors (Manandhar et al., 1995). The mean size of conidia was close to the values reported in the literature (Sutton, 1992; Rava \& Sartorato, 1994). The phenotypic variation in size was due to genetic variation $(<90 \%$, Table 3), and could originate from genetic causes or reflect genome size variation as described in Aspergillus nidulans Eidan Winter (Pontecorvo et al., 1954).

Occurrence of anastomoses among hyphae of $C$. lindemuthianum has been shown by Bos (1985) and MendesCosta et al. (1998). This is cytological evidence for the occurrence of heterokaryons. Binucleate conidia could originate during sporulation and permit the migration of one nucleus. With the most common mean of four chromosomes, nuclei with eight chromosomes could arise after fusion. The 
variation in chromosome number was likely caused by biological factors and not methodology related problems. If the variation in the number of chromosomes had been due to count errors, they would have been random, independent of the slide or the plate, and not significant causes of these variations. In two biotypes of $C$. gloeosporioides, with chromosome polymorphism, He et al. (1998) demonstrated that occasional transfer of particular chromosomes among mitosporic isolates occurred in a hereditary manner.

O'Sullivan et al. (1998) showed variation in the genome size of $C$. lindemuthianum by flow cytometry. By PFGE, these authors found total chromosome numbers that varied from nine to 12 and suggested that the chromosomes belonged to two distinct classes. One group or the first class had a variable number of small chromosomes $(<2.5 \mathrm{Mb})$, some of which were probably below the level of detection by light microscopy. However, if the variable size and number of these chromosomes are considered, this could explain the chromosome number of 16 found a few times by light microscopy in our work.

The second class of chromosomes found by O'Sullivan et al. (1998) was a set of unresolved chromosomes larger than $7 \mathrm{Mb}$ with a variation of four to nine large chromosomes (O'Sullivan et al., 1998). These could be the chromosomes most easily seen with the microscope and which are described here. It is more difficult to resolve the large chromosomes by PFGE (O'Sullivan et al., 1998). The modal number of four chromosomes was common for the three strains $(531,1002$, and 1013) used. Five and six chromosomes were the next most common values (Table 3 ). The chromosomes microscopically visible were the largest, and variations in size and number could be explained by some kind of rearrangement as shown by O'Sullivan et al. (1998). These data of ca. four chromosomes are in agreement with the number found in the sexual form and in G. cingulata from Ipomea sp. (Lucas, 1946).

There was variation in size of chromosomes viewed during the same phase in dividing conidia. Perhaps the extra small chromosomes could have originated by the breaking-up of larger chromosomes. This was suggested for $C$. gloeosporioides from Stylosanthes sp. by Masel et al. (1993), Nectria haematoccoca Berk. \& Br. by Miao et al. (1991), and C. lindemuthianum by O'Sullivan et al. (1998). For the micronuclei in conidia in our study, the genetic material may have been lost during cell division due to the breaking up or occurrence of late-segregating chromosomes. These micronuclei remained for some time in the cytoplasm until degeneration or transfer to another cell, since their presence was not commonly found in conidia during dormancy. The breaking-up of larger chromosomes and the irregular division processes that lead to chromosome polymorphism could be responsible for the genetic variation found in this species (Sicard et al., 1997). Variation in the chromosome number of the conidia was also found by O'Sullivan et al. (1998) with PFGE. Our observations are in agree with the second class of chromosomes made with PFGE. The discrimination of different values is due to our observations of each cell and not a pelleted sample.
One explanation for the underestimation of chromosome number compared with the results of O'Sullivan et al. (1998) is that small fungal chromosomes are at the limit of resolution of light microscopy. Another explanation is the clustering of chromosomes during cell divisions, as suggested in the meiosis of $N$. haematococca by Taga et al. (1998). The number of four chromosomes was also found in the microscopy study done by Lucas (1946) in Glomerella sp. isolated from Ipomea $\mathrm{sp}$. This was the most frequent number found in conidia of isolates from bean.

Finally, in agreement with Taga et al. (1998), underestimation of the chromosome number with light microscopy could occur. This underestimation is probably related with small chromosome resolution difficultie, although in this case a microscopy description could explain the presence of largest chromosomes, not resolved before by PFGE. Meiosis is a more stable process to maintain less variation in chromosome number and this occurs as a very rare event in this species. Mitosis in the asexual form has flexibility in loss and gain of chromosomes as suggested by O'Sullivan et al. (1998), which results in arrangements of the genome. In $C$. lindemuthianum where a great variation was found in the field (Siccard et al., 1997) more studies could be done to verify if this chromosome variation is affecting the pathogen-plant system.

\section{ACKNOWLEDGEMENTS}

The authors are grateful to Dr. E. Bearzoti (Department of Statistic, UFLA, Brazil), Dr. Ludwig Pfenning (Department of Phytopathology, UFLA, Brazil) and Dr. Alan Wheals (Department of Biology, University of Bath, UK) for discussions and suggestions during the preparation of the manuscript. M.G.R.M. is grateful to the Brazilian National Research Council (CNPq) for a grant and scholarship to the MSc degree.

\section{LITERATURE CITED}

BATISTA, U.G. \& CHAVES, G.M. Patogenicidade de culturas monoascospóricas de cruzamento entre raças de Colletotrichum lindemuthianum (Sacc. et Magn.) Scrib. Fitopatologia Brasileira 7:285293. 1982.

BOS, C. J. Induced mutation and somatic recombination as tools for genetic analysis and breeding of imperfect fungi. (Ph.D. Thesis). Wageningen. Wageningen Agricultural University. 1985.

BRYSON, R.J. Sexual hybridisation and the genetics of pathogenic specificity in Colletotrichum lindemuthianum. (Ph.D. Thesis). Birmingham, University of Birmingham. 1990.

CISAR, C.R. SPIEGEL, C.R. TEBEEST, D.O. \& TROUT, C. Evidence for mating between isolates of Colletotrichum gloeosporioides with different host specificities. Current Genetics 25:330-335. 1994.

EDGERTON, C.W. Plus and minus in an Ascomycete. Science 35:151. 1912.

EDGERTON, C.W. Plus and minus in the genus Glomerella. 
American Journal of Botany 1:244-254. 1914.

HE, C. RUSU, A.G. POPLAWSKI, A.M. IRWIN, J.A.G. \& MANNERS, J.M. Transfer of a supernumerary chromosome between vegetatively incompatible biotypes of the fungus Colletotrichum lindemuthianum. Genetics 150:1459-1466. 1998.

HICKS, C.R. Fundamental concepts in the design of experiments. 4th ed. Oxford. Oxford University Press. 1993.

HRUSHOVETZ, S.B. Cytological studies of ascus development in Cochiliobolus sativus. Canadian Journal of Botany 34:641-651. 1956.

HÜTTIG, N. Die Sexualität bei Glomerella lycopersici Krüger und ihre Vererbung. Biologisches Zentralblatt 55:74-83. 1935.

JUNQUEIRA, N.T.V., CHAVES, G.M., ZAMBOLIN, L., ROMEIRO, R.S. \& GASPAROTO, L. Isolamento, cultivo e esporulação de Microcylus ulei, agente etiológico do mal das folhas de seringueira. Revista Ceres 31:322-331. 1984.

KIMATI, H. \& GALLI, F. Glomerella cingulata (Stonem.) Spauld. et v. Schrenk. f.sp. phaseoli n.f., fase ascôgena do agente causal da antracnose do feijoeiro. Anais, E.S.A. "Luiz de Queiroz", Piracicaba, SP. 27:411-437. 1970.

KNOX-DAVIES, P. S. \& DICKSON, J. G. Cytology of Helminsthosporium turcicum and its ascigerous stage, Tricometasphaeria turcicum. American Journal of Botany 47:328329. 1960.

LIYANAGE, H.D., MCMILLAN, JR. \& KISTLER, H.C. Two genetically distinct populations of Colletotrichum gloeosporioides from citrus. Phytopathology 82:1371-1376. 1992.

LUCAS, G.B. Genetics of Glomerella. IV. Nuclear phenomena in the ascus. American Journal of Botany 33:802-806. 1946.

MCGAHEN, J.W. \& WHEELER, H.E. Genetics of Glomerella. IX. Perithecial development and plasmogamy. American. Journal of Botany 38:610-617. 1951.

MANANDHAR, J.B., HARTMAN, G.L. \& WANG, T.C. Conidial germination and appressorial formation of Colletotrichum capsici and C. gloeosporioides isolates from pepper. Plant Disease 79:361-366. 1995.

MASEL, A.M., BRAITHWAITE, J.I., IRWIN, J. \& MANNERS, J.M. Highly variable molecular karyotypes in the plant pathogen Colletotrichum gloeosporioides. Current Genetics 18:81-86. 1990.

MASEL, A.M., IRWIN, J. \& MANNERS, J.M. DNA addition or deletion is associated with a major karyotype polymorphism in the fungal phytopathogen Colletotrichum gloeosporioides. Molecular General Genetics 237:73-80. 1993.

MENDES-COSTA, M.C. Genetics of Glomerella cingulata f. sp. phaseoli I. Sexual compatibility. Brazilian Journal of Genetics 19:350. 1996. (abstract)
MENDES-COSTA, M.C., DAVIDE, L.C. \& ROCA M., M.G. 'In vitro' cytology of Colletotrichum lindemuthianum (Sacc. et Magn.) Scrib. Ciência e Agrotecnologia 22:250-253. 1998.

MIAO, V.P., COVERT, S.F. \& VANETTEN, H.D. A fungal gene for antibiotic resistance on a dispensable ("B") chromosome. Science 254:1773-1776. 1991.

O'SUlliVAN, D., TOSI, P., CREUSOT, F., COOKE, M., PHAN, T.H., DRON, M. \& LANGIN, T. Variation in genome organization of the plant pathogenic fungus Colletotrichum lindemuthianum. Current Genetics 33:291-298. 1998.

PERFECT, S.E., HUGHES, H.B. \& O'CONNELL, R.J. Colletotrichum: A model genus for studies on pathology and fungalplant interactions. Fungal Genetics and Biology 27:186-198. 1999.

PONTECORVO, G., GLOOR, E.T. \& FORBES, E. Analysis of mitotic recombination in Aspergillus nidulans. Journal of Genetics 52:226-237. 1954.

RAVA, A.C. \& SARTORATO, A. Antracnose. In: Sartorato, A. \& Rava, A.C. (Eds) Principais doenças do feijoeiro comum e seu controle. Brasilia. Empresa Brasileira de Pesquisa Agropecuaria, 17-40. 1994. ROBINOW, C.F. The preparation of yeast for light microscopy. In: Prescott, D.M. (Ed.) Methods in cell biology. New York. Academic Press. 1975. v.11. pp.2-21,

ROCA M., M.G. ONGARELLI, M.G. DAVIDE, L.C. \& MENDESCOSTA, M.C. Ultrastructural aspects in perithecia hyphae septal pores of Glomerella cingulata f. sp. phaseoli. Brazilian Journal of Microbiology 31:223-225. 2000.

SICARD, D., MICHALAKIS, Y., DRON, M. \& NEEMA, C. Genetic diversity and pathogenic variation of Colletorichum lindemuthianum in the three centres of origin of its wild host Phaseolus vulgaris. Phytopathology. 87:807-813. 1997.

SUTTON, B.C. The genus Glomerella and its Anamorph Colletotrichum. In: Bailey, J.A. \& Jeger, M.J. (Eds) Colletotrichum: biology, pathology and control Wallingford. C.A.B. International. 1992. pp. 1-26.

TAGA, M., MURATA, M. \& SAITO, H. Comparison of different karyotyping methods in filamentous ascomycetes - a case study of Nectria haematococca. Mycological Research 102:1355-1364. 1998.

UECKER, F. A. Ontogeny of the ascoma of Glomerella cingulata. Mycologia 86:82-88. 1994.

WHEELER, H.E. \& DRIVER, C.H. Genetics and cytology of a mutant, dwarf-spored Glomerella. American Journal of Botany 40:694-702. 1953.

WHEELER, H.E. OLIVE, L.S. ERNEST, C.T. \& EDGERTON, C.W. Genetics of Glomerella. V. Crozier and ascus development. American Journal of Botany 35:722-728. 1948. 